\title{
KESIAPAN IMPLEMENTASI STANDAR AKUNTANSI PEMERINTAHAN BERBASIS AKRUAL
}

\author{
Lilik Suroya ${ }^{a}$ \\ Heru Tjaraka ${ }^{b}$ \\ ${ }^{a}$ Sekolah Pascasarjana Universitas Airlangga ${ }^{b}$ Fakultas Ekonomi dan Bisnis Universitas Airlangga \\ Email: suroyalilik@yahoo.com ${ }^{\text {a }}$, heru tjaraka@yahoo.co.id ${ }^{\text {b }}$
}

ARTICLE HISTORY

Received:

15 August 2020

Revised

9 September 2020

Accepted:

5 Oktober 2020

Online available:

24 November 2020

Keywords:

Kesiapan

implementasi,

Standar Akuntansi

Pemerintahan

Berbasis Akrual

\section{ABSTRACT}

Introduction: This study will identify the readiness to implement the Accrual-Based Government Accounting Standards in the regional public hospital dr. Soedono Madiun.

Methods: This research uses a qualitative approach with an explanatory case study method. Implementation of accrual-based Government Accounting Standards must be implemented in 2015 in accordance with the Law of the Republic of Indonesia No. 17 of 2003 concerning State Finance.

Results: Human resources in the Finance Department in implementing accrual-based government accounting standards are considered inadequate or inadequate, but the management of RSUD dr. Soedono Madiun strives by disseminating the understanding of accrual accounting, improving formal education, and training so that it has benefits to improve accounting understanding and improve the quality of human resources.

Conclusion and suggestion: The main obstacle in the readiness to implement accrual-based Government Accounting Standards is the provincial level legal basis in the form of a Governor Regulation concerning Accrual-based Accounting Policies which underlie Government Regulation No. 71/2010 does not yet exist. 


\section{INTRODUCTION}

Pemerintah Indonesia tengah melakukan perubahan pengelolaan keuangan sebagai upaya dalam memenuhi tuntutan rakyat sebagai pemilik kekayaan negara. Perubahan pengelolaan keuangan terdapat dalam Undang-Undang No. 17 Tahun 2003 Tentang Keuangan Negara, Undang-Undang No 1 Tahun 2004 Tentang Perbendaharaan Negara dan Undang-Undang No. 15 Tahun 2004 Tentang Pemeriksaan Pengelolaan dan Tanggung Jawab Keuangan Negara. Salah satu perubahan pengelolaan keuangan adalah adanya perubahan basis akuntansi yang dipakai dalam rangka penyusunan laporan keuangan yang transparan, efektif dan efisien dengan meningkatkan akuntabilitas dan transparansi. Pengelolaan keuangan dan perubahan basis akuntansi dari basis kas menjadi basis akrual tertuang dalam Undang-Undang No 17 Tahun 2003 tentang Keuangan Negara, pasal 36 ayat (1) menyatakan bahwa pengakuan dan pengukuran pendapatan dan belanja berbasis akrual dilaksanakan selambat-lambatnya dalam 5 (lima) tahun. Selama pengakuan dan pengukuran pendapatan dan belanja berbasis akrual belum dilaksanakan, digunakan pengakuan dan pengukuran berbasis kas

Laporan keuangan merupakan alat pertanggungjawaban pemerintah dalam pengelolaan sumber daya ekonomi yang dimiliki yaitu dengan mengelola pengeluaran dan pendapatan yang didapat dari masyarakat dan untuk memberikan pelayanan kepada masyarakat. Di dalam Undang-Undang No 17 tahun 2003 yaitu penyusunan penyajian laporan keuangan pusat dan daerah didasarkan pada Standar Akuntansi Pemerintahan. Penerbitan Peraturan Pemerintah No. 71 Tahun 2010 tentang Standar Akuntansi Pemerintahan berbasis akrual penuh sebagai pengganti Peraturan Pemerintah No. 24 Tahun 2005 yang menggunakan basis akuntansi cash toward accrual (CTA) diharapkan dapat memberikan landasan penerapan akuntansi pemerintahan yang lebih baik.

Pada saat ini dengan menggunakan Cash Towards Accrual maka basis akuntansi untuk pengakuan pendapatan, belanja dan pembiayaan dalam LRA menggunakan basis Kas. Pengakuan asset, kewajiban, dan ekuitas dalam Neraca menggunakan basis akrual. Apabila telah menggunakan akrual secara penuh maka pengakuan pendapatan dalam Laporan Operasional, beban, asset, kewajiban dan ekuitas menggunakan basis akrual.

Rumah Sakit Umum Daerah dr. Soedono Madiun merupakan Satuan Kerja Perangkat Daerah Propinsi sebagai Pengguna Anggaran / Barang dengan istilah entitas akuntansi yang mempunyai kewajiban menyelenggarakan akuntansi dan penyusunan pelaporan keuangan untuk digabungkan pada entitas pelaporan secara periodik dan melakukan rekonsiliasi atas laporan keuangan hal ini terdapat dalam Undang-Undang no 1 tahun 2004 tentang Perbendaharaan Negara pada pasal 6 ayat 1 dan ayat 2 .

Published by University of Airlangga.

This is an open access article under the CC BY license (https://creativecommons.org/licenses/by-sa/4.0/) 
Rumah sakit Umum Daerah dr. Soedono Madiun juga merupakan Badan Layanan Umum Daerah yang dibentuk untuk memberikan pelayanan kepada masyarakat berupa penyediaan barang dan/atau jasa yang dijual tanpa mengutamakan mencari keuntungan, dan dalam melakukan kegiatannya didasarkan pada prinsip efisiensi dan produktivitas menurut Peraturan Pemerintah No 23 tahun 2005 tentang Pengelolaan Keuangan Badan Layanan Umum Pasal 14 poin kedua yang berbunyi pendapatan yang diperoleh dari jasa layanan yang diberikan kepada masyarakat dan hibah tidak terikat dan yang diperoleh dari masyarakat atau badan lain merupakan pendapatan operasional BLU.

Standar Akuntansi Pemerintahan Berbasis Akrual (Peraturan Pemerintah Nomor 71 Tahun 2010) harus dilaksanakan pada tahun 2015 dengan beberapa tantangan antara lain informasi teknologi, sumber daya manusia, komitmen dari pimpinan, resistensi terhadap perubahan (Simanjuntak, 2010; 13). Implementasi Standar Akuntansi Pemerintahan Berbasis Akrual yang harus dilaksanakan pada tahun 2015 dalam penelitian ini akan mengidentifikasikan Kesiapan implementasi Standar Akuntansi Pemerintahan Berbasis Akrual di RSUD dr. Soedono Madiun.

\section{LITERATURE REVIEW}

\section{The traditional society}

\section{Peranan Teknologi Informasi Dalam Implementasi Standar Akuntansi Pemerintahan}

Teknologi informasi merupakan istilah yang hampir sama dengan sistem informasi manajemen, sistem teknologi informasi dimana teknoogi informasi berarti mengolah data dengan menggunakan peralatan dan mesin yang canggih yang didalamnya terdapat teknik dan proses mengubah masukan menjadi keluaran sehingga memudahkan manusia untuk beraktifitas dan data dapat diolah dengan cepat. Menurut Mohyi $(2012,73)$ teknologi adalah berkaitan dengan peralatan dan mesin canggih yang memberi kemudahan bagi manusia untuk beraktifitas.

Pengelolaan keuangan pemerintah Indonesia tengah melakukan perubahan sebagai upaya dalam memenuhi tuntutan rakyat sebagai pemilik kekayaan negara Salah satu perubahan pengelolaan keuangan adalah adanya perubahan basis akuntansi yang dipakai dalam rangka penyusunan laporan keuangan yang transparan, efektif dan efisien dengan meningkatkan akuntabilitas dan transparansi. Pengelolaan keuangan dan perubahan basis akuntansi dari basis kas menjadi basis akrual dan sebagai acuan terdapat dalam Peraturan Pemerintah No. 24 tahun 2005 tentang Standar Akuntansi Pemerintahan berbasis kas menuju akrual yang kemudian dirubah seiring amanat Undang-Undang No 17 Tahun 2003 tentang Keuangan Negara untuk menghasilkan laporan keuangan yang lebih transparan dan akuntabel dengan menggunakan basis akrual. Perubahan menjadi Peraturan Pemerintah No 71. Tahun 2010 tentang Standar Akuntansi Pemerintahan berbasis akrual. 
Peraturan Pemerintah No. 56 tahun 2005 tentang Sistem Informasi Keuangan Daerah sebagai acuan sistem informasi yang dilaksanakan dalam pengelolaan keuangan daerah. Hal ini menunjukkan bahwa sistem informasi sangat diperlukan dalam menyajikan informasi berupa laporan keuangan. Peranan Sistem informasi dalam kaitan dengan Implementasi Standar Akuntansi Pemerintahan Berbasis Akrual yang akan dilaksanakan pada tahun 2015 memerlukan penyesuaian pada proses pengolahan data melalui prosedur akuntansi yang semula kas menuju akrual menjadi prosedur akuntansi akrual agar laporan keuangan yang disajikan transparan, dan akuntanbel sesuai dengan Peraturan Pemerintah No 71 tahun 2010 tentang Standar Akuntansi Pemerintahan Berbasis Akrual dan Peraturan Pemerintah No. 56 Tahun 2005 tentang Sistem Informasi Keuangan Daerah (SIKD).

Peranan Sumber Daya Manusia Dalam Implementasi Standar Akuntansi Pemerintahan

Sumber daya manusia dalam suatu organisasi adalah manusia atau orang yang bekerja dan beraktifitas mencapai tujuan organisasi biasa disebut personil, pegawai, karyawan, pekerja, tenaga kerja dan lain-lain. Manusia adalah sumber daya ciptaan Tuhan Yang Maha Esa yang mempunyai sikap dan tindakan yang menunjukkan pribadi, potensi yang dapat mempengaruhi organisasi. Faktor yang mempengaruhi sikap dan tindakan manusia dalam organisasi:
a. Umur
b. Jenis kelamin
c. Pendidikan
d. Belajar
e. Motivasi

\section{Perubahan Perlakuan Akuntansi}

Pengelolaan keuangan pemerintah Indonesia tengah melakukan perubahan sebagai upaya dalam memenuhi tuntutan rakyat sebagai pemilik kekayaan negara Salah satu perubahan pengelolaan keuangan adalah adanya perubahan basis akuntansi yang dipakai dalam rangka penyusunan laporan keuangan yang transparan, efektif dan efisien dengan meningkatkan akuntabilitas dan transparansi. Perubahan basis akuntansi yang dipakai dalam penyusunan laporan keuangan adalah basis akuntansi kas menjadi basis akuntansi akrual. Perubahan terjadi karena manfaat basis akuntansi akrual sangat penting untuk memenuhi tuntutan rakyat. Menurut Menurut Khan dan Mayes, 2009 dalam IPSASB $(2011,12)$ Manfaat Akuntansi Akrual Informasi yang terkandung dalam laporan disusun atas dasar akrual berguna baik untuk akuntabilitas dan pengambilan keputusan.

Published by University of Airlangga.

This is an open access article under the CC BY license (https://creativecommons.org/licenses/by-sa/4.0/) 
Sedangkan menurut Damayanti (2013) akuntansi akrual dianggap memberikan benefit yang besar kepada penggunanya. Akuntansi akrual memberikan informasi yang lebih bisa diandalkan karena mampu memberikan informasi tentang kewajiban dan hak yang akan diterima di masa depan sehingga keputusan ekonomi dapat diambil lebih baik Sehingga basis akuntansi akrual sangat penting untuk pengambilan keputusan. Sedangkan pelayanan kepada masyarakat yang diberikan oleh pemerintah harus lebih ditingkatkan dengan memberikan pelayanan yang sebaik-baiknya tanpa mencari keuntungan.

Perubahan perlakuan akuntansi telah diditentukan dengan terbitnya Peraturan Pemerintah No 24 tahun 2005 tentang Standar Akuntansi Pemrintahan Berbasis Kas Menuju Akrual yang kemudian diganti dengan Peraturan Pemerintah No. 71 Tahun 2010 tentang Standar Akuntansi Pemerintahan Berbasis Akrual yang implementasinya pada tahun 2015 dengan mempunyai tantangan antara lain tentang sistem (teknologi) informasi yang sedang berjalan dan persiapan perubahannya. Penggunanan sistem (teknologi) informasi dalam implementasi akuntansi akrual akan memudahkan dan mempercepat proses penyusunan laporan keuangan yang digunakan dalam pengambilan keputusan,. Tantangan lainnya keahlian manusia yang terkait dengan adanya perubahan tersebut. Manusia atau karyawan dengan keahlian akuntansi akan mudah mengimplementasikan keahlian yang dimiliki kedalam proses penyusunan laporan keuangan.

\section{Standar Akuntansi Pemerintahan}

Menurut Peraturan Pemerintah Nomo 71 Tahun 2010 adalah Standar Akuntansi Pemerintahan, yang selanjutnya disingkat SAP, adalah prinsip-prinsip akuntansi yang diterapkan dalam menyusun dan menyajikan laporan keuangan pemerintah.

1. Standar Akuntansi Pemerintahan Berbasis Kas Menuju Akrual (Peraturan Pemerintah Nomor 24 Tahun 2005).

2. Standar Akuntansi Pemerintahan Berbasis Akrual (Peraturan Pemerintah Nomor 71 tahun 2010).

\section{Previous Study}

Penelitian tentang Kesiapan Implementasi Standar Akuntansi Berbasis Akrual sangat terbatas. Beberapa penelitian terdahulu yang dijadikan acuan antara lain :

1. Faradillah (2013) melakukan penelitian dengan judul "Analisis kesiapan pemerintah daerah dalam menerapkan standar akuntansi pemerintahan (peraturan pemerintah Nomor 71 tahun 2010) dikota Makasar" Persamaan penelitian Faradillah dengan penelitian ini adalah ditinjau dari kesiapan implementasi standar akuntansi pemerintahan berbasis akrual. Perbedaan penelitian Faradillah dengan peneliatian ini adalah : untuk penelitian Faradillah melakukan penelitian dari sisi budaya organisasi sedangkan penelitian ini menekankan pada aspek sumber daya manusia, 
informasi teknologi dan perubahan perlakuan akuntansi dalam implementasi Standar Akuntansi Pemerintahan berbasis Akrual

2. Kusuma (2013) melakukan penelitian dengan judul "Analisis kesiapan pemerintah dalam menerapkan standar akuntansi pemerintahan berbasis akrual (kasus pada pemerintah kabupaten Jember). Persamaan penelitian Kusuma dengan penelitian ini adalah yaitu sama-sama mengindikasikan kesiapan implementasi standar akuntansi pemerintahan berbasis akrual dari segi sumber daya manusia, informasi teknologi. Perbedaan penelitian Kusuma dengan penelitian ini adalah dilihat dari parameter integritas adalah kategori siap dan untuk kesiapan SDM, kesiapan sistem informasi dan sarana prasarana adalah kategori cukup siap.

3. Tarigan (2012) melakukan penelitian dengan judul " Standar Akuntansi Pemerintahan Dalam Mewujudkan Akuntabilitas dan Transaparansi Pengelolaan Keuangan Daerah Pada Dinas Pajak Daerah dan Pengelolaan Keuangan Kota Yogyakarta. Persamaan penelitian Tarigan dengan penelitian ini adalah ditinjau dari kesiapan implementasi standar akuntansi pemerintahan berbasis akrual. . Perbedaan penelitian Tarigan adalah adanya faktor internal (komitmen pimpinan daerah, integritas dan profesionalisme birokrat, ketersediaan sarana dan prasarana dan permasalahn asset tetap pemerintah) dan eksternal (tidak konsistennya peraturan, pemahaman DPRD belum memadai dan opini BPK-RI) menjadi alasan belum diterapkannya basis akrual tersebut walaupun diyakini dapat menjaga keberadaan asset daerah sedangkan penelitian ini menekankan pada aspek sumber daya manusia, informasi teknologi dan perubahan perlakuan akuntansi dalam implementasi Standar Akuntansi Pemerintahan berbasis Akrual

4. Novalina (2011) Analisis Kesiapan Pemerintah Daerah Dalam Menerapkan Standar Akuntansi Pemerintah Berbasis Akrual (Studi Pada Pemerintah Kabupaten Sampang) Persamaan penelitian Novalina dengan penelitian ini yaitu sama-sama berdasarkan pengetahuan tentang standar akuntansi pemerintahan berbasis kas menuju akrual dan berbasis akrual serta mengindikasikan kesiapan implementasi standar akuntansi pemerintahan berbasis akrual dari segi sumber daya manusia, informasi teknologi, sarana prasarana Perbedaan penelitian Novalina adalah Pemerintah Kabupaten Sampang belum siap dalam menerapkan Standar Akuntansi Pemerintahan Berbasis Akrual (PP No. 71 Tahun 2010) karena masih perlu pembenahan terhadap sumber daya manusia, kebijakan, dan infrastruktur untuk mendukung penerapan SAP berbasis akrual.

5. Eriotis (2011) Assessing Accrual Accounting Reform in Greek Public Hospitals: An Empirical Investigation. Persamaan penelitian Eriotis dengan penelitian ini yaitu 
sama-sama menilai reformasi akuntansi akrual segi sumber daya manusia, komitmen pimpinan, sarana prasarana, informasi teknologi . Perbedaan penelitian Eriotis adalah tingkat adopsi reformasi secara positif berhubungan dengan kualitas IT, reformasi terkait,pelatihan, tingkat pendidikan staf akuntansi, dan dukungan konsultan professional namun ada hubungan yang signifikan yang ditemukan antara tingkat adopsi reformasi dan ukuran rumah sakit, biaya pelaksanaan reformasi, CEO latar belakang pendidikan, pengalaman efek, dan tidak adanya hubungan konflik manajemen-dokter.

\section{RESEARCH METHODS}

Penelitian ini menggunakan pendekatan kualitatif dengan metode studi kasus eksplanatory. Implementasi Standar Akuntansi Pemerintahan berbasis akrual harus dilaksanakan pada tahun 2015 sesuai dengan Undang-Undang Republik Indonesia No. 17 tahun 2003 tentang Keuangan Negara. Penelitian ini untuk memperoleh penjelasan tentang kesiapan Implementasi Standar Akuntansi Pemerintahan berbasis akrual di RSUD dr. Soedono Madiun.

\section{RESULT AND ANALYSIS}

\section{Tingkat Pengetahuan PP 24 Tahun 2005}

Tingkat pengetahuan tentang Peraturan Pemerintah No 24 tahun 2005 tentang Standar AKuntansi Pemerintahan berbasis kas menuju akrual oleh staf keuanga dan akuntansi RSUD dr. Soedono Madiun sebesar 74\% berarti hamper seluruh mengetahui Standar Akuntansi Pemerintahan berbasis kas menuju akrual

Tabel 1

Tingkat Pengetahuan Staf Keuangan dan Akuntansi

RSUD dr. Soedono Madiun terhadap PP 24 Tahun 2005

\begin{tabular}{|c|c|c|c|c|}
\hline PP 24 Tahun 2005 tentang Standar Akuntansi & \multicolumn{2}{|c|}{ Mengetahui } & \multicolumn{2}{|c|}{ Tidak Mengetahui } \\
\hline Pemerintahan Berbasis kas menuju Akrual & Frek & $(\%)$ & Frek & $(\%)$ \\
\hline $\begin{array}{l}\text { Menurut Standar Akuntansi Pemerintahan } \\
\text { berbasis kas menuju akrual komponen laporan } \\
\text { keuangan terdiri dari Laporan Realisasi } \\
\text { Anggaran, Neraca, Laporan Arus Kas, Catatan } \\
\text { atas Laporan Keuangan? }\end{array}$ & 18 & $75 \%$ & 6 & $25 \%$ \\
\hline $\begin{array}{l}\text { Menurut Standar Akuntansi Pemerintahan } \\
\text { berbasis kas menuju akrual pemeliharaan } \\
\text { asset tetap yang bersifat rutin dan berkala } \\
\text { dikapitalisasi }\end{array}$ & 1 & $4 \%$ & 23 & $96 \%$ \\
\hline Jumlah & & $74 \%$ & & $26 \%$ \\
\hline
\end{tabular}

Sumber : Data Hasil Olahan, 2014 
Penyusunan laporan keuangan menurut PP 24 Tahun 2005 Tentang Standar Akuntansi Pemerintahan Berbasis Kas Menuju Akrual tidak ada kesulitan dengan alasan:

1. Peraturan Gubernur Jawa Timur No 91 Tahun 2011 tentang Kebijakan Akuntansi Badan Layanan Umum Daerah Provinsi Jawa Timur dan Pedoman Kerja dan Pelaksanaan Tugas Pemerintah Daerah Propinsi Jawa Timur yang didalamnya berisi Kebijakan Akuntansi yang digunakan adalah basis Kas Menuju Akrual.

2. Saat ini menggunakan SIKDA (sistem informasi keuangan daerah) karena memang kebijakan dari Pemerintah Propinsi Jawa Timur menggunakan Kas Menuju Akrual dan merupakan program dari Pemerintah Propinsi Jawa Timur.

\section{Tingkat Pengetahuan PP71 tahun 2010}

Seluruh staf Keuangan dan Akuntansi RSUD dr. Soedono Madiun mengetahui Peraturan Pemerintah No 71 Tahun 2010 tentang Standar Akuntansi Pemerintahan berbasis akrual yaitu sebesar $97 \%$.

Tabel 2

Tingkat Pengetahuan Staf Keuangan dan Akuntansi

RSUD dr. Soedono Madiun terhadap PP 71 Tahun 2010

\begin{tabular}{|c|c|c|c|c|c|}
\hline \multirow{2}{*}{ No } & PP 71 Tahun 2010 tentang Standar Akuntansi & \multicolumn{2}{|c|}{ Paham } & \multicolumn{2}{|c|}{ Tidak Paham } \\
\hline & Pemerintahan Berbasis Akrual & Frek & (\%) & Frek & (\%) \\
\hline 1 & $\begin{array}{l}\text { Secara konseptual akuntansi berbasis akrual akan } \\
\text { menghasilkan informasi yang lebih akuntabel dan } \\
\text { transparansi dibandingkan dengan akuntansi berbasis } \\
\text { kas }\end{array}$ & 24 & $100 \%$ & 0 & $0 \%$ \\
\hline 2 & $\begin{array}{l}\text { Akuntansi berbasis akrual adalah basis akuntansi di } \\
\text { mana transaksi ekonomi dan peristiwa lainnya diakui, } \\
\text { dicatat dan disajikan dalam laporan keuangan pada } \\
\text { saat terjadinya transaksi tersebut. }\end{array}$ & 24 & $100 \%$ & 0 & $0 \%$ \\
\hline 3 & $\begin{array}{l}\text { Pendapatan menurut basis akrual diakui pada saat } \\
\text { timbulnya hak atas pendapatan tersebut }\end{array}$ & 24 & $100 \%$ & 0 & $0 \%$ \\
\hline 4 & $\begin{array}{l}\text { Belanja menurut basis akrual diakui pada saat } \\
\text { timbulnya kewajiban atau pada saat diperoleh manfaat }\end{array}$ & 23 & $96 \%$ & 1 & $4 \%$ \\
\hline 5 & $\begin{array}{l}\text { Menurut Standar Akuntansi Pemerintahan berbasis } \\
\text { akrual, Laporan Realisasi Anggaran tetap disajikan } \\
\text { menggunakan akuntansi berbasis kas }\end{array}$ & 21 & $87 \%$ & 3 & $13 \%$ \\
\hline 6 & $\begin{array}{l}\text { Menurut Standar Akuntansi Pemerintahan berbasis } \\
\text { akrual, Laporan Operasional diperlukan untuk } \\
\text { menyajikan informasi mengenai kinerja suatu } \\
\text { organisasi dalam mengumpulkan dan menggunakan } \\
\text { sumber daya ekonomi sehingga pendapatan dan belanja } \\
\text { diukur dengan basis akrual. }\end{array}$ & 24 & $100 \%$ & 0 & $0 \%$ \\
\hline
\end{tabular}

Sumber : Data Hasil Olahan, 2014

Published by University of Airlangga.

This is an open access article under the CC BY license (https://creativecommons.org/licenses/by-sa/4.0/) 
Para staf keuangan dan akuntansi RSUD dr. Soedono Madiun mengetahui tentang adanya Standar Akuntansi Pemerintahan berbasis akrual (PP No. 71 Th. 2010 ). Sumber daya manusia di Bagian Keuangan RSUD dr. Soedono Madiun dalam implementasi Standar akuntansi pemerintahan berbasis akrual dinilai kurang siap atau belum memadai tetapi pihak manajemen RSUD dr. Soedono Madiun berupaya dengan melakukan sosialisasi pemahaman akuntansi akrual, peningkatan pendidikan formal, dan pelatihan sehingga mempunyai manfaat untuk meningkatkan pemahaman akuntansi dan meningkatkan kualitas sumber daya manusia.

Implementasi Standar Akuntansi Pemerintahan berbasis akrual memerlukan sarana dan prasarana fisik dan informasi teknologi. Sarana prasarana fisik di RSUD dr. Soedono Madiun dalam keadaan memadai, sedangkan berkaitan dengan Informasi teknologi memerlukan penyempurnaan dalam penyesuaian dengan akuntansi akrual.

Kesiapan dari segi komitmen pimpinan Direktur beserta jajaran direksi mendukung implementasi Standar AKuntansi Pemerintahan Berbasis Akrual. Besarnya komitmen pimpinan ini ditunjukkan dengan berinisiatif mengundang pakar untuk melakukan sosialisasi dan persiapan-persiapan meskipun kebijakan ditingkat propinsi belum diberlakukan.

Kendala implementasi Standar Akuntansi Pemerintahan Berbasis akrual adalah belum ada pemahaman akuntansi akrual untuk semua profesi sedangkan landasan hokum belum adanya Peraturan Gubernur tentang pelaksanan PP 71 tahun 2010 belum ada dan pemahaman akuntansi akrual sumber daya manusia unit terkait yang perlu dilakukan sosialisasi.

\section{CONCLUSION}

Berdasarkan hasil analisis dan pembahasan, maka penelitian ini dapat disimpulkan bahwa kesiapan implementasi Standar Akuntasi Pemerintahan berbasis akrual di RSUD dr. Soedono Madiun dan upaya pihak manajemen dapat dilihat bahwa

Sumber daya manusia di Bagian Keuangan RSUD dr. Soedono Madiun dalam implementasi Standar akuntansi pemerintahan berbasis akrual dinilai kurang siap atau belum memadai tetapi pihak manajemen RSUD dr. Soedono Madiun berupaya dengan melakukan sosialisasi pemahaman akuntansi akrual, peningkatan pendidikan formal, dan pelatihan sehingga mempunyai manfaat untuk meningkatkan pemahaman akuntansi dan meningkatkan kualitas sumber daya manusia.

Informasi teknologi dalam implementasi Standar Akuntansi Pemerintahan berbasis Akrual adalah Informasi teknologi yang ada saat ini dalam upaya penyempurnaan sesuai keinginan, yaitu basis akrual. Meskipun kesiapan implementasi Standar Akuntansi Pemerintahan berbasis akrual di RSUD dr. Soedono Madiun dari sumber daya manusia dan informasi teknologi telah dilakukan upaya yaitu sosialisasi 
pemahaman akuntansi akrual, peningkatan pendidikan formal, dan mengikuti pelatihan yang ada serta menyempurnakan informasi teknologi/sistem informasi yang telah ada agar sesuai dengan keinginan yaitu akuntansi akrual tetapi RSUD dr. Soedono Madiun masih mempunyai kendala. Kendala utama dalam kesiapan implementasi Standar Akuntasi Pemerintahan berbasis akrual adalah landasan hukum Tingkat Propinsi berupa Peraturan Gubernur tentang Kebijakan Akuntansi berbasis akrual yang melandasi Peraturan Pemerintah No 71 tahun 2010 belum ada.

Kendala kedua adalah ketidaksiapan sumber daya manusia di unit terkait, Implementasi standar akuntansi pemerintahan berbasis akrual melibatkan unit lain antara lain data penerimaan pendapatan berasal dari tarif tindakan yang dilakukan oleh medis dan paramedis. Rekapitulasi tindakan medis dan paramedis sebagai dasar pembayaran pasien yang merupakan pendapatan rumah sakit. Pengakuan pendapatan akan mempengaruhi akuntansi akrual sehingga peran sumber daya manusia unit terkait dalam hal ini sumber daya manusia medis dan paramedis juga berperan dalam implementasi standar akuntansi pemerintahan berbasis akrual.

\section{REFERENCES}

Ardiansyah 2013 Factors Affecting The Affecting The Readiness of PP No. 71 Tahun 2010 About Government Accounting Standards (Case Study on Working Units in KPPN Malang's Working Area) diakses www.jimfeb.ub.ac.id/index.php/jimfeb/article/download/255/204 tanggal 7 Mei 2013

Baswir, Revrisond 2000 Akuntansi Pemerintahan Indonesia, Yogyakarta BPFE

Damayanti, Ratna, 2013 Akuntansi Akrual dan Penerapannya Di Sektor Publik Sebuah Agenda Pembaruan www.starbpkp.com/download/7/modul-program-beasiswastar 13 Juni 2014

Eriotis (2011) Assessing Accrual Accounting Reform in Greek Public Hospitals: An Empirical Investigation, International Journal of Economic Sciences and Applied Research 4 (1): 153-183 www.ijesar.org/docs/volume4 issue1/volume4 issue1.pdf 25/6/2013

Faradilah Andi (2013) Analisis Kesiapan Pemerintah Daerah Dalam Menerapkan Standar Akuntansi Pemerintahan (Peraturan Pemerintah NOmor 71 Tahun 2010) diakses (www. repository.unhas.ac.id) tanggal 9/3/2014

Hariyanto Agus Penggunaan Basis Akrual Dalam Akuntansi Pemerintahan di Indonesia Jurnal Dharma Ekonomi No. 36/ Th.XIX/Oktober 2012 diakses www.ejurnal.stiedharmaputra tanggal 7 Mei 2013

International Public Sector Accounting Standars Board 2011, Transition to the Accrual Basis of Accounting : Guidance For Public Sector Entities Third Edition International Federation of Accountants diakses 
www.ifac.org/sites/default/files/publications/.../IPSASB-study-14-3e.pdf tanggal 10 Juli 2014

Jogiyanto, 2008 Sistem Teknologi Informasi Andi Yogyakarta

Kesit, Bambang 2011 Modul Akuntansi Pemerintahan diakses (www.bambangkesit.wordpress.com tanggal 26 Agustus 2013)

Kusuma, Riris 2013 Analisis Kesiapan Pemerintah Dalam Menerapkan Standar Akuntansi Pemerintahan Berbasis Akrual (Kasus pada Pemerintah Kabupaten Jember) diakses (www.repository.unej.ac.id) tanggal 9/3/2014

Komite Standar Akuntansi Pemerintahan, 2010 Buletin Teknis Standar AKuntansi Pemerintahan Nomor 09 Akuntansi Aset Tetap diakses (www.ksap.org/Buletin/Bultek 09 Akuntansi Aset \%20Tetap.pdf) pada tanggal $5 / 6 / 2014$

Meidyawati 2011 Analisis Implementasi Pola Pengelolaan Keuangan Badan Layanan Umum (PPK-BLUD) Pada Rumah Sakit stroke Nasional Bukittinggi (Online) ( www.pasca.unand.ac.id tanggal 27 Pebruari 2013)

Mohyi, A Drs 2012 Teori Dan Perilaku Organisasi Membentuk mengelola, mendeteksi Kepribadian, Efektifitas Dan Mengembangkan Organisasi UMMPress Malang

Moorhead dan Griffin 2013 Perilaku Organisasi Manajemen Sumber Daya Manusia dan Organisasi Penerbit Salemba Empat

Mukhyi tanpa tahun Pengantar Akuntansi Pemerintahan diakses (www.mukhyi.staff.gunadarma.ac.id tanggal 21 Agustus 2013)

Mulyana B.__. Penggunaan Akuntansi Akrual di Negara-Negara Lain:Tren di Negara-negara Anggota OECD sutaryofe.staff.uns.ac.id/files/2011/10/Akuntansiberbasis-akrual.pdf 27/3/2013

Novalina, Eka 2011 Analisis Kesiapan Pemerintah Daerah Dalam Menerapkan Standar Akuntansi Pemerintahan Berbasis Akrual (Studi Pada Pemerintahan Kabupaten Sampang) Fakultas Ekonomi dan Bisnis Universitas Airlangga Surabaya

Peraturan Pemerintah Republik Indonesia Nomor 24 Tahun 2005 Tentang Standar Akuntansi Pemerintahan diakses www.bpkp.go.id tanggal 30 Agustus 2013

Peraturan Pemerintah Republik Indonesia Nomor 58 Tahun 2005 Tentang Pengelolaan Keuangan Daerah www.bpk.go.id tanggal 5 September 2013

Peraturan Pemerintah Republik Indonesia Nomor 71 Tahun 2010 Tentang Standar Akuntansi Pemerintahan diperbanyak oleh Penerbit Salemba Empat

Peraturan Menteri Dalam Negeri Nomor 61 Tahun 2007 Tentang Pedoman Teknis Pengelolaan Keuangan Badan Layanan Umum www.kemendagri.go.id tanggal 5 Septemebr 2013

Peraturan Menteri Kesehatan Nomor 340/MENKES/PER/III/2010 Tentang Klaasifikasi Rumah Sakit www.hukor.depkes.go.id tanggal 5 September 2013

Peraturan Daerah Provinsi Jawa Timur Nomor 12 Tahun 2008 Tentang Organisasi dan Tatakerja Badan Koordinasi Wilayah Pemerintahan dan Pembangunan Jawa Timur www. ro-organisasi.jatimprov.go.id. tanggal 5 September 2013

RSUD dr. Soedono Madiun Catatan Atas Laporan Keuangan 2012 
Simanjuntak, Binsar 2010 Penerapan Akuntansi Berbasis Akrual Di Sektor Pemerintahan di Indonesia (Online) (www.iaiglobal.or.id diakses 15 juli 2013)

Sinaga,Jamason 2006 Selamat datang Standar Akuntansi Pemerintahan - KSAP diakses www.ksap.org tangal 26 Agustus 2013

Sinaga,Jamason 2007 Jurnal Korolari dalam Penerapan Standar Akuntansi Pemerintahan diakses ksap.org/Riset\&Artikel/Art10.pdf tanggal 29 April 2014

Tarigan Erwinton 2012 Standar Akuntansi Pemerintahan Dalam Mewujudkan Akuntabilitas dan Transparansi Pengelolaan Keuangan Daerah Pada Dinas Pajak Daerah dan Pengelolaan Keuangan Kota Yogyakarta

Undang-Undang Nomor 17 Tahun 2003 Tentang Keuangan Negara www.perbendaharaan.go.id tanggal 5 September 2013

Undang-Undang Nomor 1 Tahun 2004 Tentang Perbendaharaan Negara www.bpk.go.id tanggal 5 September 2013

Undang-Undang Nomor 15 Tahun 2004 Tentang Pemeriksaan Pengelolaan dan Tanggung Jawab Keuangan Negara www.bpk.go.id tanggal 5 September 2013

Undang-Undang Nomor 44 Tahun 2009 Tentang Rumah Sakit

Universitas Airlangga Fakultas Ekonomi 2009 Pedoman Penulisan Usulan Penelitian dan Tesis

Yin, Robert K Studi Kasus (Desain dan Metode) terjemahan oleh M. Djauzi Mudzakir PT RajaGrafindo Persada Jakarta 2002 